\title{
ELEVATING THE MANA OF SOIL THROUGH THE HUA PARAKORE FRAMEWORK
}

\author{
Jessica Hutchings* \\ Jo Smith ${ }^{\dagger}$ \\ Garth Harmsworth
}

\begin{abstract}
How might Māori values in relation to soil contribute to national strategies for identifying, maintaining and enhancing soil health? This article uses the Hua Parakore framework, a kaupapa Māori approach developed out of the Māori organics sector, to address these questions. Soil is an essential national resource on which New Zealand's primary sector and agriculture industries depend. Soil is also part of the woven universe constituting Māori ways of knowing and doing (Marsden, 2003). Māori agricultural and horticultural practices also make a significant contribution to the New Zealand farming and agribusiness sector, mainly in pastoralism, dairying and forestry (Harmsworth \& Roskruge, 2014). Combining both cultural and economic interests, the stakes are high for Māori in contributing to a sustainable national soil resource base. This article takes a focused look at how Te Ao Māori values can be used to understand concepts around soil health and provide a framework for soil resource management in order to elevate this issue in the public's mind. We argue that wider understanding of the Māori values and worldviews as they apply to soil health - that is, elevating the mana of soil in the nation's consciousness-might bring into sharper relief the ways in which kaupapa Māori approaches, including mātauranga Māori, can contribute to national strategies for healthy soil.
\end{abstract}

* Ngāi Tahu. Director, Tiaho Ltd, Kaitoke, Upper Hutt, New Zealand. Email: jvhutchings@gmail.com

† Ngāi Tahu. Associate Professor, School of English, Film, Theatre and Media Studies, Victoria University of Wellington, New Zealand.

‡ Te Arawa, Ngāti Tuwharetoa, Tuhourangi, Ngāti Raukawa. Toi Rangahau—Māori Research Leader (Senior Scientist Environmental), Manaaki Whenua — Landcare Research, Palmerston North, New Zealand.

DOI: 10.20507/MAIJournal.2018.7.1.8 


\section{Keywords}

Hua Parakore, soil, kaupapa Māori, values, mana

\section{Introduction}

Arguments about the Rights of Nature have recently prevailed in Aotearoa New Zealand, with the Te Urewera Act 2014 and the Whanganui River Act 2017 assigning "personhood" to a once-titled "Conservation Park" and a wounded waterway, respectively. Māori law expert Jacinta Ruru described the potential impact of the 2014 Te Urewera settlement in the following way:

What's really exciting about it is it creates an entirely new, respectful, way for all parties to engage with that land and that place. ... A way of recognising that they have their own heartbeat, their own place, and their own identity. (as quoted in Mitchell, 2016, para.14)

This important legal shift is a direct reflection of the values underpinning Te Ao Māori perspectives of te taiao and opens up opportunities for wider understanding of the indivisible relationship between Indigenous people, values and landscapes. Another public debate reflecting Māori values and natural resources includes ownership and rights to fresh water, as exemplified by current debates about private interests selling bottled versions of the water resource. The rights, ownership and protection of natural resources such as land and water are obvious topics of debate for Indigenous peoples in Aotearoa, and internationally. Indigenous issues in the United States, such as the ownership and rights of cultural lands, have been highlighted through the recent Standing Rock confrontations over extensive US government and private oil pipeline interventions and expansions across tribal lands.

This article explores the concept of mana and rights to manage resources, and then discusses soil management and soil health from a kaupapa Māori perspective which frames soil health within the Hua Parakore framework that is underpinned by Māori values. Drawing on a kaupapa Māori approach developed out of the Māori organics sector, the Hua Parakore framework, this article provides insights into how mātauranga Māori and Māori values are used to understand and conceptualise soil health relative to a wider issue of food sovereignty. We provide a Hua Parakore approach and guidance for how the soil ecosystem can be managed in line with Te Ao Māori worldviews. We argue that wider understanding of Māori values and worldviews can help frame and guide approaches to soil and bring into sharper relief the ways in which mātauranga Māori can contribute to national strategies for healthy soil. Māori worldviews related to soil and the interconnectedness of natural and human elements (denoted in the concept of tangata whenua) are reflected in the following whakatauki, which helps guide the discussion that follows:

Ma te Hua Parakore e tiaki te ora o te pae o Papatūānuku, te ora o ngā hua me ngā rākau katoa a Tāne, otirā, te oranga tinana o ngā tāngata katoa [Hua Parakore maintains healthy soils, healthy plants and healthy people]. (Hutchings, 2015, p. 26)

In order to explain how soil is part of the woven universe that constitutes Te Ao Māori, the following section discusses some of the broader cultural concepts (whakapapa, kaitiakitanga and ki uta ki tai) that help frame tangata whenua relationships, as well as some of the legislative mechanisms used to shape Māori resource management and decision-making practices. 


\section{A wider context for thinking about Māori values related to soil}

The concept of whakapapa encourages a focus on the origins of the name attached to soil. Whakapapa refers to concepts of genealogy and relatedness, and provides a taxonomy system for ordering nature. Oneone is the general term used to describe soil, and "one" is often used as the prefix to clarify different soil types (Harmsworth \& Roskruge, 2014, p. 118). As with many Māori terms, there is a cosmological dimension to "oneone". "One" derives from the first woman, Hine-ahu-one, formed from clay by the hand of Tāne, one of the many sons of the Earth deity Papatūānuku. Māori values and worldviews flow from an understanding that ancestral ties or whakapapa link Māori to the natural world, as well as to each other. Hence the term tangata whenua, people of the land, which is used to refer to Māori, itself a term that only came into existence with the advent of colonisation (King, 1985; McLintock, 1966). According to Harmsworth and Roskruge (2014), this whakapapa relationship "places human beings (e.g., Māori) in an environmental context with all other flora and fauna and natural resources as part of a hierarchical genetic assemblage with identifiable and established bonds" (p. 112).

Acknowledgement of the mutual bond between peoples, plants, landscapes and waterways underpins much of the contemporary environment and resource management practices of Māori (Awatere \& Harmsworth, 2014; Reid, Barr, \& Lambert, 2013; Roskruge, 2007; Tanner et al., 2017). The phrase "ki uta ki tai" ("from the mountains to the sea") is a dominant paradigm in these sectors and describes a "whole of landscape" approach that emphasises interconnectivity between all elements and entities (Roskruge, 2007).

Soil, too, is part of this complex woven system. Generally, it is composed of mineral particles from weathered rock (45\%), water $(25 \%)$, air $(25 \%)$ and organic matter and living microorganisms $(1 \%-5 \%)$ (Hutchings, 2015). Accordingly, a handful of soil, from a Māori-values point of view, embodies a complex whakapapa of relationships with mutually sustaining obligations. This is demonstrated when one takes an Atua domains viewpoint related to soil that sees soil as Hine-ahu-one, air as Tawhirimatea and water as Tangaroa. Looking at soil through an Atua domain lens centres the whakapapa relationships within soil as being primary. This chimes with a "whole of landscape" approach that also includes Mãori as kaitiaki of the environment with obligations to care for lands and waters, or as Roskruge (2007) has argued, "While the [natural] resources sustain us as a people they also need to be sustained by the people" (p. 25).

While the broader cultural concepts of whakapapa, kaitiakitanga and ki uta ki tai help guide Māori worldviews of soil, the practical implementation of these worldviews (resource management and decision-making practices) often requires engagement with, and negotiation of, wider non-Māori forces. For example, while a whānau, hapū or iwi might decide to protect the waterways running through their territories, they have very little power to effect changes in non-Māori practices upstream from the borders of their lands, thus restricting a ki uta ki tai approach. There are three broad areas related to how Māori can make decisions about soil management. The first relates to local and tribal territories, including kāinga, māra kai, marae, iwi/hapū tribal areas, Māori land, customary land, and collectives. The second relates to the interface with local authorities (e.g., landscapes, catchments), with legislation, such as the Resource Management Act 1991 and Local Government Act 2002, and the National Policy Statement 2011 on freshwater management including Māori values as an essential requirement for decision-making and practices. The third occurs at the level of the state, in terms of national strategies, policy and priorities that reflect the Treaty of Waitangi and other legislation. 
This necessary engagement with non-Māori decision-makers means that communicating the value of Māori worldviews is a priority area of consideration. At times, larger and more obvious land and water issues obscure the matter of soil and its fundamental role in Māori agricultural and horticultural practices. Communicating the site-specific and relational nature of a ki uta ki tai approach to natural resources elevates the elements within landscapes and waterways (e.g., soil) as meaningful actors in their own right. Focusing on the attributes that constitute healthy soil and the practices that might enhance this health requires a similarly site-specific approach. The following section outlines the Māori values and worldviews related to the niche food sovereignty practice of Hua Parakore, a guideline for soil resource management to support mahinga kai, with the intent of expanding the existing vocabulary for understanding what constitutes healthy soil.

\section{Hua Parakore as a framework for thinking about soil}

Hua Parakore is a kaupapa Māori framework for growing organic kai. More specifically, it is an Indigenous validation and verification system for the production of pure food or kai atua. The framework was first developed by Te Waka Kai Ora (National Māori Organics Group) and established through a three-year kaupapa Māori research project that involved Māori organic growers, traditional healers and community researchers from across Aotearoa (Hutchings et al., 2012). Since its 2011 launch, the Hua Parakore framework has seen a rich uptake from kaupapa Māori growers across Aotearoa and has become part of Māori education curricula, with tertiary courses now being offered in Kai Oranga and Hua Parakore. In many ways the framework is an expression of the wider concept of Indigenous food sovereignty, which expands the notion of Indigenous sovereignty over lands and waterways to now encompass the range of ecosystems and essential components (e.g., seeds, soils, pest management) upon which local Indigenous food systems rely. At an international level Hua Parakore is useful for considering a range of complex issues, including sustainable land management, biodiversity, resource management, climate change, peak oil and food sovereignty.

The Hua Parakore framework is based on six interrelated kaupapa Māori principles, drawn from a mātauranga Māori continuum, through which diverse tikanga of whānau, hapū and iwi can be applied in order to produce kai atua. The six principles are whakapapa, wairua, māramatanga, mauri, mana and Te Ao Tūroa. These principles are not the only ones that can be used to organise kai atua practices, but they provide a strong tikanga basis and starting point to guide Māori organic growers. Indeed, in keeping with the kaupapa of māramatanga, the Hua Parakore framework is a dynamic one, designed to be shaped and shifted in light of evolving practices and changing conditions. As Hutchings (2015) states, "The system continues to be innovated by Hua Parakore growers through their growing practices and through the sharing of knowledge and experience at wānanga with other Hua Parakore growers" (p. 22).

The Hua Parakore is based on mātauranga Māori and tikanga to provide a Te Ao Māori perspective that can be used as a foundation for understanding essential ecosystems and components that support kai atua. We contend therefore that it can be used to understand soil ecosystems both within the specific context of Indigenous food sovereignty and food production more generally. In this respect it can be used to provide a pathway for building new Māori knowledge and thus extend current understandings of what constitutes healthy soil. This is because the first principle of producing kai atua is to have healthy soil. In Te Mahi Māra Hua Parakore: A Māori Food Sovereignty Handbook, Hutchings (2015) states: 
To the hua parakore gardener, soil is one of the most important aspects of the māra. The observation and understanding of healthy soil is essential to the practice of growing kai. Growing and maintaining healthy soil is a first priority. Soil connects us with the primal energies of Papa-tū-ā-nuku and with the cosmic energies of the universe under which the soil lives. (p. 93)

Below we provide a brief discussion around each of the six Hua Parakore principles to demonstrate their relevance for understanding and achieving healthy soil. In many ways the notion of healthy soil requires a balance between elements that echo wider Māori goals in the area of health more generally. Therefore, the six aspects of the Hua Parakore model noted below chime with other models for thinking about Māori health more generally, such as the Whare Tapa Whā, Te Pae Mahutonga and Te Wheki models (Durie, 1994, 1999; Pere, 1991).

\section{Whakapapa}

When applying the Hua Parakore concepts to understanding soil health, it is important to first understand the whakapapa of a soil, its ancestral lineage, interconnections, and links to atua. Whakapapa brings an Indigenous ordering system to the natural world, thereby setting the context for how the world is viewed (Harmsworth \& Roskruge, 2014, p. 113). Whakapapa is about the natural order and connection between all entities, including atua, land and water, producers, and everything that is produced from the natural world. "Knowing this genealogy and how everything is interconnected and is interrelated within mahinga kai (food gathering or growing areas) is fundamental to knowing the cultural and ecological landscape of the mahinga kai" (Hutchings et al., 2012, p. 136). Recall here the relevance of Hine-ahu-one, the first human being (as derived from many tribal traditions and oral histories). It is her formation from the earthly soils that created human life and therefore the Māori cultural landscape holds a divine presence that is maintained through this whakapapa relationship. What then can the kaupapa of whakapapa offer in enhancing the quality and quantity of soils to sustain livelihoods? Modern expressions can be seen through the livelihood of farmers, healthy food production, communities, ecosystems and cultural landscapes. We contend that by prioritising whakapapa as a primary kaupapa applied to soil health we take a "whole of landscape" approach, where the divine presence of atua relationships is considered and honoured in ways that contribute to soil quality. This could include undertaking a ki uta ki tai approach to assessing impacts on soil health in a region, with emphasis placed on understanding the whakapapa relationships of diverse Māori communities in relation to their soils.

We contend that the application of the kaupapa of whakapapa to soils would also contribute to building new mātauranga as applied to soils in specific areas, and that this has the potential to remap whakapapa values and attributes to soil profiles, use and enhancement practices. The generation of these new knowledges could present potential solutions for enhancing soil quality and provide sustainability-driven suggestions for soil use into the future. This principle seeks to maintain the whakapapa or connections in our soil ecosystems. Furthermore, when soil is seen as a divine entity, as previously described, then the fundamental kaupapa Māori question becomes "How do we retain and strengthen the whakapapa of our soils?" This implies asking not what the soil can do for us but what we can do for the soil. Reframing and shifting values applied to soil could greatly improve environmental management outcomes towards sustainably using soils in the future.

\section{Wairua}

Wairua as a Hua Parakore kaupapa refers to the "spiritual health and peace of the land, 
the food and the people" (Hutchings et al., 2012, p. 137). Hua Parakore growers describe applying wairua in their māra through karakia, which provide a way to connect with the divine energies of the cultural and physical environment they are working in. Karakia is a mindful practice that brings into focus the interconnected nature of land and water. It provides a moment to pause and to connect with the "divine senses", thereby fine-tuning the producer's observational skills.

At first, the application of wairua to soil is for the Hua Parakore grower a personal relationship between the grower and the soil, highlighting the knowledge that the soil is a spiritual entity or part of the grower's own being. This knowingness brings integrity to any work with soil, and connects the grower to the soil and to the resulting produce and kai atua. This produce then connects to those who consume the kai. The application of this divine relationship to soil has the ability to enhance the current approach that is taken to soil, widening it from one that sees it as a resource-based input for use in a production system to one in which it is revered as being sacred. Taking up a handful of soil creates a connection to place. This principle seeks to maintain the wairua of our soils, primarily through connection and tikanga (e.g., karakia). This principle recognises the continuum of wairua through the whole system, from the soil to the kai, which in turn raises many questions in terms of how we use soil and how soil should be managed.

\section{Māramatanga}

Māramatanga in a Hua Parakore context is about enlightenment and insight: it emphasises the development of observational skills and understanding nature. With relation to soil, this kaupapa provides guidance for the Hua Parakore producer to cultivate divine senses to smell, feel and register the vibration of the soil in order to understand its wellbeing. This principle seeks to maintain the seasonal and natural cycles in our soil and food ecosystems through enlightenment and insight, requiring the producer to connect with natural cycles. It can be used to guide practices to achieve balance and maintain and enhance wellbeing. A set of indicators can be used to identify māramatanga in our practices. These practices may include, for example, following the māramataka and incantations to invoke deities, as well as observing environmental indicators and applying local knowledge of the seasons (Hutchings et al., 2012).

\section{Mauri}

Mauri in a Hua Parakore context is the principal essence of life; it is the energy and the vibration that is required to produce kai atua. Within a Hua Parakore framework, it is not enough to just maintain the mauri of a resource: practices must also enhance mauri. Within the verification system underpinning a Hua Parakore framework there are specific questions asked of Māori producers about the tikanga they engage to maintain healthy soils, such as composting practices and the use of livestock to enhance soil fertility. Soil is a key focus of the Hua Parakore approach for producing kai and emphasis is placed on developing and growing producers' knowledge and cultural practices for enhancing the mauri of the soil. In particular, methods for supporting and growing soil microbial diversity are important. Soil is home to the largest proportion of the world's biodiversity, so undertaking practices that grow knowledge of supporting a "whole of soil" ecosystem approach is important. For the Hua Parakore producer some of these practices include reduced use of mechanised equipment to minimise soil compaction, growing nitrogenfixing green crops which will protect the soil structure and reduce soil erosion, working within a closed-loop system (no external elements brought to the farm) with minimal inputs and adding organic matter to the soil. 
Mana

In a Hua Parakore context, "Mana is the autonomy, security and self-determination of Māori tribal collectives as expressed through mahinga kai" (Hutchings et al., 2012, p. 138). Both mauri and mana can be diminished through human activity. If you care for the soil and improve microbiology, then you enhance the wellbeing of the soil, which in turn enhances the mana of the soil. There are numerous practices of mana in a Hua Parakore context that have been noted by producers. The most common is through the expression of manaakitanga, which is most commonly described as the maintenance of whakapapa relationships of reciprocity. This is enacted through the sharing of food that contributes to the social cohesion amongst whānau, hapū and iwi. This in turn means that growing kai is something you don't do just for yourself but is something that is undertaken for a wider purpose and to be shared with the collective.

Within the Hua Parakore verification system the principle of mana also pertains to food sovereignty and food security of the whole food production system. "Māori food sovereignty in Aotearoa puts Māori who produce, distribute and consume food-rather than the demands of global markets, free trade agreements and corporations-at the heart of food systems and policies" (Hutchings, 2015, p. 38).

\section{Te Ao Tūroa}

As noted before, a key feature of the Hua Parakore system is the "whole of landscape" approach, also understood as ki uta ki tai or $\mathrm{Te}$ Ao Tūroa. Te Ao Tūroa is the natural order of the living world which humans are an inextricable part of. This Hua Parakore kaupapa gives expression to the role of whānau, hapū and iwi as kaitiaki to Te Ao Tūroa as the home of kai atua (Hutchings et al., 2012). In this regard, the role of Hua Parakore producers is to respect the sanctity and integrity of the natural order. The applications of tikanga include a resistance to inputs that can disrupt the natural order, such as chemical fertilisers, pesticides, herbicides, genetic modification and nanotechnology. Hua Parakore producers are asked to provide a list of inputs and to complete a soil test to ensure pathways for maintaining this natural order can be enacted. Emphasis is placed on understanding the practices that Hua Parakore producers have in place to mitigate the contamination of Te Ao Tūroa and in particular soils. The indivisible and mutually dependent relationship between nature and peoples is expressed in the whakataukī cited earlier: "Hua Parakore maintains healthy soils, healthy plants and healthy people" (Te Waka Kai Ora, 2011, p. 22). This speaks to the Hua Parakore producers' roles as kaitiaki of Te Ao Tūroa.

\section{Discussion: Implications of the Hua Parakore framework for defining healthy soils}

The Hua Parakore framework provides a Māoricentred approach for determining concepts and understanding of what constitutes soil health and human wellbeing. It can guide resource management practice through kaitiakitanga by identifying whether the system is in balance or not. The framework reinforces the need to establish local markets and locally sourced food as part of a wider discourse on food sovereignty, especially where living economies seek to "empower whānau and hapū driven food production, distribution and consumption, based on environmental, social, cultural and economic sustainability" (Hutchings, 2015, p. 38). Most importantly, "it promotes ancestral foodways and revitalises Indigenous food knowledges that make cultural, ecological and economic sense" (p. 38). The notion of soil sovereignty is critical in a Māori food sovereignty context; it elevates the importance of soil in the food system, as a critical living system, with billions of organisms weaving an intricate food web. As soil expert Albert Howard argues, 
"The birthright of every crop is health", and health begins in the soil (as cited in Shumei International Institute \& Navdanya, 2015, p. 11). A Hua Parakore view of soil sees it as the basis of life and food. Discourses of soil sovereignty are imperative to advocate for the biological integrity of soils. We contend that our relationship as Indigenous peoples with the soil has been fractured, as is described in the Soil Manifesto published in Visions of the Living Soil (2015):

The rupture in our relationship with the soil began with the enclosure of commons and the takeover of lands through colonialism. It continued with the rise of industrial agriculture, which is based on a mechanistic paradigm. The dependence on fossil fuels has created an ignorance of and blindness to the living processes that create a living soil. Instead of focusing on the Soil Food Web, it has been obsessed with the external input of chemical fertilisers-what Sir Albert Howard called the NPK mentality (NPK stands for, nitrogen, phosphorus and potassium, the three nutrients that compose complete fertilisers). The biology of the living soil has been replaced with industrial chemistry. Soil has been reduced to dirt and made inert, an empty container, only to hold chemicals. (Shumei International Institute \& Navdanya, 2015, p. 90)

How might a kaupapa Māori framework related to a niche horticultural sector complement national strategies for enhancing soil health? The nationally funded research initiative Soil Health: Oneone Ora, Tangata Ora seeks to achieve healthy resilient soils by 2020 as $17 \%$ of New Zealand's GDP depends on "the top $15 \mathrm{~cm}$ of our soil” (AgResearch, 2011, para. 3). Māori agricultural and horticultural practices make a significant contribution to the New Zealand farming and agribusiness sector (Harmsworth \& Roskruge, 2014, p. 123). Therefore, the stakes are high for Māori in contributing to a sustainable national soil resource base. The kaupapa of Te Ao Tūroa that grounds the Hua Parakore framework is consistent with the "whole of landscape" approach taken in Māori environment and resource management sectors. Yet, when considering the interconnectedness of lands, waterways and soil, kaupapa Māori practices on Māori lands are significantly constrained by those non-Māori land owners who perpetuate an extractive approach to soil as a resource, asking only, "What can this soil do for us?" The overall purpose of understanding soil from a Hua Parakore framework is to raise the profile of soil itself as an entity with its own heartbeat and identity - to paraphrase Ruru's comments cited earlier-and to ask "What can we do for the soil?" This means raising the mana of soil and highlighting the interrelated nature of whole landscapes and peoples.

An important first step in raising the profile of soil as a living entity is to clearly communicate the particular whakapapa of particular soils in particular places and to understand how we need to work in a relational manner so that the link between soil and peoples is maintained and enriched. Whakapapa also relates to those materials used to enrich the health of soil, such as composting and other additives. We need to ask "Where do these materials come from and do they enhance or inhibit relationships between soil and people?" Drawing on the kaupapa of wairua strengthens awareness of this whakapapa, sharpening observational skills and bringing new perspectives to bear on the relatedness of soil, soil moisture, soil biodiversity and seasonal changes. Practising wairuatanga contributes to greater understanding or māramatanga. Wairuatanga sharpens our divine senses and builds greater literacy about the vibrations of nature as a living, breathing entity. However, we suggest that we need to draw on all available knowledge sources and tools, combining them with our divine senses, in order to make sense of the world. Kaupapa Māori as well as tools based on Western science and deemed most appropriate by Māori together provide extensive knowledge of soils 
in order to understand their current state or condition and the pressures and impacts they are under. A combined approach will enable us to sustainably manage soils through, for example, innovative soil practices that draw from several knowledge systems. The kaupapa of mauri provides a key objective for developing research related to soil: How can this research enhance and extend the mauri of soil and people, including biodiversity? Existing kaupapa Māori tools increasingly being used to help understand the concepts of mauri for resource management include, for example, the Mauri Meter and Mauri Compass (Morgan, 2007; Ruru, 2015).

We argue that, when used together, the kaupapa principles in the Hua Parakore framework have the potential to heal the sometimes fractured relationship between people and soil that has been historically imposed on Māori communities as a result of ongoing forms of settler colonialism (Smith, 2011). In this regard, we argue that returning mana to the soil is about restoring and re-establishing the mana relationship between whānau, hapū, iwi and soil, and about sustaining the relationship where it has not been so fractured. It is about resisting the reduction of land, water and earth-our soil-as a commodity "to simply be speculated on and grabbed" (Shumei International Institute \& Navdanya, 2015, p. 90). We suggest that understanding soil as a living, breathing entity—as Hine-ahu-one-with all the kaitiaki obligations attached to such recognition, is the next step that must be taken in building a national strategy around good practice and management of soil, a step perhaps as revolutionary as those taken to acknowledge the personhood (as a living entity) of Te Urewera and Whanganui River.

\section{Conclusion}

This article has used a kaupapa Māori approach and framework to understand concepts of soil

health and what constitutes healthy soil. Soil as a living and breathing ecosystem is central to Māori values, beliefs and knowledge. Hua Parakore, an Indigenous verification and validation system, provides a mātauranga Māori and tikanga basis for understanding and guiding resource management. We argue that Māori values in relation to soil can contribute to national strategies for identifying, maintaining and enhancing soil health in order to achieve healthy soils and food production from a Māori perspective.

The Hua Parakore framework provides six guiding kaupapa principles which can be used together to identify balance in a soil ecosystem, and therefore used to provide guidelines and practices to identify, restore, maintain and enhance soil health. In this respect, returning mana to a soil is seen as critically important to re-establish and strengthen the relationship between people—whānau, hapū, iwi-and soil. Hua Parakore can be used to guide resource management, and is highly suited for inclusion in local and national strategies requiring a $\mathrm{Te}$ Ao Māori focus for sustainable land and soil management.

\section{Glossary}

Aotearoa

atua

hapū

Hine-ahu-one

hua parakore

iwi

kai

kai atua

kāinga

kaitiaki
Māori name for New Zealand; lit. "land of the long white cloud" deity

a group of whānau with a common ancestor

female element formed from soil

pure Māori produce free from harmful chemicals tribal grouping food pure food home, dwelling, habitat guardian 


\begin{tabular}{|c|c|}
\hline kaitiakitanga & guardianship \\
\hline karakia & incantation \\
\hline kaupapa & $\begin{array}{l}\text { Māori principle, ways of } \\
\text { knowing and doing }\end{array}$ \\
\hline ki uta ki tai & $\begin{array}{l}\text { a "whole of landscape" } \\
\text { approach; lit. "from the } \\
\text { mountains to the sea" }\end{array}$ \\
\hline mahinga kai & $\begin{array}{l}\text { food gathering, food } \\
\text { growing }\end{array}$ \\
\hline mana & authority, prestige \\
\hline manaakitanga & reciprocity \\
\hline māra kai & food garden \\
\hline marae & meeting grounds \\
\hline māramataka & $\begin{array}{l}\text { traditional planting } \\
\text { calendar }\end{array}$ \\
\hline māramatanga & $\begin{array}{l}\text { enlightenment, insight, } \\
\text { clarity }\end{array}$ \\
\hline mātauranga & $\begin{array}{l}\text { knowledge, tradition, } \\
\text { epistemology }\end{array}$ \\
\hline mauri & life force \\
\hline oneone & soil \\
\hline Papatūānuku & Earth Mother \\
\hline Tāne & deity of forests and birds \\
\hline Tangaroa & deity of the ocean \\
\hline tangata whenua & people of the land \\
\hline Tawhirimatea & deity of the winds \\
\hline Te Ao Māori & Māori world \\
\hline Te Ao Tūroa & the natural world \\
\hline te taiao & environment \\
\hline tikanga & Māori practices \\
\hline wairua & spirit \\
\hline wairuatanga & spirituality \\
\hline wānanga & place of higher learning \\
\hline whakapapa & genealogical ties, ordering \\
\hline & $\begin{array}{l}\text { system for the natural } \\
\text { world }\end{array}$ \\
\hline whakataukī & proverb \\
\hline whānau & extended family grouping \\
\hline & $\begin{array}{l}\text { either through kinship or } \\
\text { kaupapa }\end{array}$ \\
\hline
\end{tabular}

\section{References}

AgResearch. (2011, June 3). Industry and councils to get the dirt on soil research. Retrieved from http://www.climatecloud.org.nz/news/pages/ news-item.aspx?News-id=11-06-03-03

Awatere, S., \& Harmsworth, G. (2014). Ngā aroturukitanga tika mō ngā kaitiaki: Summary review of mātauranga Māori frameworks, approaches, and culturally appropriate monitoring tools for management of mahinga kai. Hamilton, New Zealand: University of Waikato.

Durie, M. (1994). Whaiaora: Māori health development. Auckland, New Zealand: Oxford University Press.

Durie, M. (1999, December). Te Pae Mahutonga: A model for Māori health promotion. Health Promotion Forum of New Zealand Newsletter, 49, 2-5.

Harmsworth, G., \& Roskruge, N. (2014). Indigenous Māori values, perspectives, and knowledge of soils in Aotearoa-New Zealand: Māori use and knowledge of soils over time. In G. J. Churchman \&E. R. Landa(Eds.), In the soilunderfoot: Infinite possibilities for a finite resource (pp. 257-268). Boca Raton, FL: CRC Press. http://doi.org/ckm5

Hutchings, J. (2015). Te mahi māra hua parakore: A Māori food sovereignty handbook. Ōtaki, New Zealand: Te Tākupu, Te Wānanga o Raukawa.

Hutchings, J., Tipene, P., Carney, C., Greensill, A., Skelton, P., \& Baker, M. (2012). Hua Parakore, an Indigenous food sovereignty initiative and hallmark of excellence for food and product production. MAI Journal, 1(2), 131-145.

King, M. (1985). Being Pakeha. Auckland, New Zealand: Hodder and Stoughton.

Marsden, M. (2003). The woven universe: Selected writings of Rev. Māori Marsden (T. A. C. Royal, Ed.). Ōtaki, New Zealand: Estate of Rev. Māori Marsden.

McLintock, A. H. (1966). Encyclopaedia of New Zealand. Wellington, New Zealand: Government Printer.

Mitchell, T. (2016). In New Zealand, the land can be a person. Meanwhile in Australia ... New Matilda. Retrieved from https://newmatilda. com/2016/09/08/new-zealand-land-can-personmeanwhile-australia

Morgan, K. (2007). Waiora and cultural identity: Water quality assessment using the Mauri model. Alternative, 3(1), 42-67. http://doi.org/ckm6 
Pere, R. (1991). Te Wheke: A celebration of infinite wisdom. Gisborne, New Zealand: Ao Ako Global Learning.

Reid, J., Barr, T., \& Lambert, S. (2013). Indigenous sustainability indicators for Māori farming and fishing enterprises: A theoretical framework. Retrieved from http://www.nzdashboard.org.nz/ uploads/2/3/7/3/23730248/13_06_indigenous_ sustainability_indicators_for_maori_farming and_fishing_enterprises_reid_final.pdf

Roskruge, N. (2007). Hokia ki te whenua (Unpublished $\mathrm{PhD}$ thesis). Massey University, Palmerston North, New Zealand.

Ruru, I. (2015). The Mauri Compass: A concept paper showing the Mauri Compass as an evaluation tool in a RMA freshwater context. Gisborne, New Zealand: Te Rūnanga o Turanganui a Kiwa. Shumei International Institute \& Navdanya. (2015). Visions of the living soil. Crestone, CO: Shumei International Press.
Smith, J. (2011). Aotearoa/New Zealand: An unsettled state in a sea of islands. Settler Colonial Studies, 1(1), 111-131. http://doi.org/ckm7

Tanner, C., Muirhead, R., Burger, D., Carrick, S., Close, M., Monaghan, R., . . . Tipa, G. (2017). A framework for understanding the linkages between land and water quality impacts. In L. D. Currie \& M. J. Hedley (Eds.), Science and policy: Nutrient management challenges for the next generation (Occasional Report No. 30, pp. 1-10). Palmerston North, New Zealand: Fertilizer and Lime Research Centre, Massey University.

Te Waka Kai Ora. (2011). Nga kaupapa o Hua Parakore. Wellington, New Zealand: Author. 